Disclosure of Interests: None declared.

DOI: 10.1136/annrheumdis-2021-eular.2844

\section{POS1139 COMPARISON OF THE FREQUENCY OF DETECTION OF EARLY SIGNS OF ATHEROSCLEROSIS IN PATIENTS WITH CALCIUM PYROPHOSPHATE CRYSTAL DEPOSITION DISEASE AND OSTEOARTHRITIS}

M. Eliseev ${ }^{1}$, A. Novikova ${ }^{1}$, O. Sheliabina ${ }^{1}$, M. Chikina ${ }^{1}$, E. Markelova ${ }^{2} .{ }^{1}$ VA Nasonova Research Institute of Rheumatology, Laboratory of Microcrystalline Arthritis, Moscow, Russian Federation; ${ }^{2}$ VA Nasonova Research Institute of Rheumatology, Laboratory of Systemic Rheumatic Diseases, Moscow, Russian Federation

Background: Crystal-induced inflammation can significantly increase cardiovascular risk (CVR) and cause early development of atherosclerosis [1]. However, no studies have been performed in patients with calcium pyrophosphate crystal deposition disease (CPPD).

Objectives: To compare the presence of atherosclerosis early signs (increased thickness of the intima-media complex (CIMT)) in patients with CPPD and osteoarthritis (OA).

Methods: A cross-sectional study included 48 patients, aged 18 to 65 years, 26 patients with crystal-verified diagnosis of CPPD (McCarty criteria) (6 (23\%) men and 20 (77\%) women) and 22 patients with OA (7 (32\%) men and $15(68 \%)$ women). Exclusion criteria are the presence of other rheumatic diseases with symptoms of arthritis, diabetes mellitus, coronary heart disease (CHD), prior myocardial infarction, stroke or myocardial revascularization surgery, estimated glomerular filtration rate (eGFR) $<60 \mathrm{ml} / \mathrm{min} / 1.73 \mathrm{~m} 2$, high and very high CVR on the SCORE scale. The examination of the patients included the history taking, assessment of anthropometric parameters and the following laboratory tests: determination of serum creatinine level (eGFR according to the MDRD formula), total cholesterol (TC), high density lipoprotein cholesterol (HDL cholesterol) and low density lipoprotein cholesterol (LDL cholesterol), C-reactive protein (CRP). Doppler ultrasound of the carotid arteries with an assessment of the thickness of the intima media complex (CIMT) was made for all patients - CIMT up to $0.9 \mathrm{~mm}$ was taken as the norm, CIMT $>0.9 \mathrm{~mm}$ and $<1.3 \mathrm{~mm}$ as increased, and CIMT $>1.3 \mathrm{~mm}$ was regarded as an atherosclerotic plaque. Statistica 12.0 package was used for statistical data processing.

Results: The groups were completely comparable by gender, age and all laboratory parameters (see Table 1), an increase in CRP $>5 \mathrm{mg} / \mathrm{l}$ was more often detected in patients with CPPD $-31 \%$ vs $14 \%$ patients with OA $(p=0.16)$.

Table 1. Clinical characteristics of patients included in the study.

\begin{tabular}{|c|c|c|c|}
\hline Parameters & CPPD $(n=26)$ & $O A(n=22)$ & $\begin{array}{c}p \text { value (reliable } \\
\text { at } p<0,05 \text { ) }\end{array}$ \\
\hline Age, years $\mathrm{M} \pm \mathrm{SD}$ & $55.9 \pm 5.9$ & $52.4 \pm 8.3$ & 0.14 \\
\hline Gender, men/women,n (\%) & $6(23) / 20(77)$ & $7(32) / 15(68)$ & 0.50 \\
\hline Smoking, n (\%) & $5(19)$ & $6(27)$ & 0.50 \\
\hline Systolic blood pressure, $\mathrm{mmHg}, \mathrm{M} \pm \mathrm{SD}$ & $134 \pm 20$ & $127 \pm 15$ & 0.19 \\
\hline Arterial hypertension, $\mathrm{n}(\%)$ & $13(50)$ & $10(45)$ & 0.75 \\
\hline Family history of CVD, $\mathrm{n} \%$ & $6(23)$ & $7(32)$ & 0.50 \\
\hline $\mathrm{TC}, \mathrm{mmol} / \mathrm{L}, \mathrm{M} \pm \mathrm{SD}$ & $5.4 \pm 1.3$ & $5.3 \pm 1.3$ & 0.95 \\
\hline $\mathrm{TC}>5,0 \mathrm{mmol} / \mathrm{L}, \mathrm{n}(\%)$ & $17(65)$ & $10(45)$ & 0.17 \\
\hline $\mathrm{HDL}, \mathrm{mmol} / \mathrm{L} \mathrm{M} \pm \mathrm{SD}$ & $1.7 \pm 0.5$ & $1.4 \pm 0.5$ & 0.10 \\
\hline $\mathrm{LDL}, \mathrm{mmol} / \mathrm{L}, \mathrm{M} \pm \mathrm{SD}$ & $2.9 \pm 1.3$ & $3.4 \pm 1.4$ & 0.33 \\
\hline Creatinine, $\mu \mathrm{mol} / \mathrm{l}, \mathrm{M} \pm \mathrm{SD}$ & $73.2 \pm 13.8$ & $78.9 \pm 11.5$ & 0.16 \\
\hline CRP, mg/l, Me [25-75th percentiles] & $1.1[0.6 ; 6.4]$ & $1.2[0.3 ; 2.8]$ & 0.60 \\
\hline $\mathrm{CRP} \geq 5 \mathrm{mg} / \mathrm{l}, \mathrm{n}(\%)$ & $8(31)$ & $3(14)$ & 0.16 \\
\hline
\end{tabular}

Mean CIMT values on the right $(0.76 \pm 0.22 \mathrm{~mm}$ vs $0.70 \pm 0.18 \mathrm{~mm})$ and on the left $(0.75 \pm 0.18 \mathrm{~mm}$ vs $0.70 \pm 0.17 \mathrm{~mm})$ did not significantly differ in CPPD and $\mathrm{OA}(\mathrm{p}=0.34$ and 0.32 , respectively), the maximum CIMT values on the right $(0.67 \pm 0.16 \mathrm{~mm}$ vs $0.67 \pm 0.16 \mathrm{~mm})$ and on the left $(0.67 \pm 0.14 \mathrm{~mm}$ vs $0.66 \pm 0.16 \mathrm{~mm})$ with CPPD and $\mathrm{OA}$ were also comparable $(\mathrm{p}=0.95$ and 0.77 , respectively). However, an increase in CIMT>0.9 mm was found in $13(50 \%)$ patients with CPPD and only $5(23 \%)$ with OA $(p=0.02)$. No increase in CIMT $>1.3 \mathrm{~mm}$ was found in patients of both groups.

Conclusion: Early signs of atherosclerosis are detected in $50 \%$ of patients with CPPD without clinical signs of atherosclerosis and with low or moderate CVR according to SCORE, significantly more often than in patients with OA (23\%), which can be reflection of chronic crystal-induced inflammation.

\section{REFERENCES:}

[1] Hoseini Z, Sepahvand F, Rashidi B, Sahebkar A, Masoudifar A, Mirzaei H. NLRP3 inflammasome: Its regulation and involvement in atherosclerosis. $J$ Cell Physiol. 2018 Mar;233(3):2116-2132. doi: 10.1002/jcp.25930. Epub 2017 May 23. PMID: 28345767.

Disclosure of Interests: Maxim Eliseev Speakers bureau: Berlin Chemie Menarini Group, Novartis International AG, EGIS, Aleksandra Novikova: None declared, Olga Sheliabina: None declared, Maria Chikina: None declared, Eugenia Markelova: None declared.

DOI: 10.1136/annrheumdis-2021-eular.3121

\section{POS1140 RISK FACTORS FOR THE DEVELOPMENT OF DIABETES MELLITUS IN PATIENTS WITH GOUT ACCORDING TO A 6-YEAR PROSPECTIVE FOLLOW-UP STUDY}

O. Sheliabina ${ }^{1}$, M. Eliseev ${ }^{1}$, A. Novikova ${ }^{1}$, M. Chikina ${ }^{1} .{ }^{1}$ VA Nasonova Research Institute of Rheumatology, Laboratory of Microcrystalline Arthritis, Moscow, Russian Federation

Background: Gout is often associated with diabetes mellitus (DM), but the role of serum uric acid (sUA) and urate-lowering drugs in its development in patients with gout remains controversial [1].

Objectives: To study risk factors for DM in patients with gout based on the results of long-term prospective follow-up study.

Methods: The prospective study included 444 patients with a crystal-verified diagnosis of gout, aged $\geq 18$ years, $49(11 \%)$ women, $395(89 \%)$ men. Patients were followed up at the V.A. Nasonova Research Institute of Rheumatology from 2010 to January 2021, the median follow-up was 6.1 [2.8; 7.8] years. The exclusion criteria were the presence of other rheumatic diseases with symptoms of arthritis, DM. DM was diagnosed on the 1998 WHO criteria. The following parameters were considered as risk factors: gender, family history for diabetes mellitus, body mass index $(\mathrm{BMI})>25 \mathrm{~kg} / \mathrm{m} 2$ and $>30 \mathrm{~kg} / \mathrm{m} 2$, waist volume $\geq 88 \mathrm{~cm}$ for women and $\geq 102 \mathrm{~cm}$ for men, alcohol consumption $>20$ units per week, chronic kidney disease (CKD), intake of diuretics and glucocorticoids, and serum total cholesterol $>5 \mathrm{mmol} / \mathrm{l}$, triglycerides $>2.25 \mathrm{mmol} / \mathrm{l}$ serum C-reactive protein (CRP) level $>5 \mathrm{mg} / \mathrm{l}$, as well as clinical manifestations of gout: subcutaneous tophi, polyarthritis (simultaneous involvement of $\geq 5$ joints), intake of urate-lowering drugs, sUA ( $>480 \mu \mathrm{mol} / \mathrm{L},>420 \mu \mathrm{mol} / \mathrm{L},>$ $360 \mu \mathrm{mol} / \mathrm{L},>300 \mu \mathrm{mol} / \mathrm{L})$. Statistica 12.0 package was used for statistical data processing.

Results: A total of 444 patients were included, the mean age was $51.0 \pm 12.9$ years, the median follow-up was $6.1[2.8 ; 7.8]$ years. In dynamics: $35(8 \%)$ patients died, $6(1 \%)$ patients were not available, 403 patients were examined $(44(11 \%)$ - women and 359 (89\%) - men). 290 (72\%) patients received urate-lowering therapy (263 (65\%) patients used allopurinol, $27(7 \%)$ - febuxostat). The target sUA $<360 \mu \mathrm{mol} / \mathrm{L}$ was reached by $165(41 \%)$ patients and $<300 \mu \mathrm{mol} / \mathrm{L}$ - by $92(23 \%)$ patients. All patients with $\mathrm{sUA}<300 \mu \mathrm{mol} / \mathrm{L}$ received urate-lowering therapy, 62 (67\%) patients used allopurinol, $17(18 \%)$ - febuxostat, $13(14 \%)$ - uricosuric drugs. Diabetes mellitus was developed in 106 (26\%) patients. The factors influencing the risk of developing diabetes were - the presence of diabetes in family history (odds ratio (OR) 2.27, 95\% confidence interval $(\mathrm{Cl}) 1.37 ; 3.76$ ); $\mathrm{BMl}>30 \mathrm{~kg}$ / $\mathrm{m} 2$ (OR 1.79, 95\% Cl 1.14; 2.80), diuretics (OR 2.32, 95\% Cl 1.36; 3.96) and sUA $>300 \mu \mathrm{mol} /$ I (OR 2.89, 95\% Cl 1.50, 5.56).

Conclusion: The risk of developing DM in patients with gout is associated with sUA $>300 \mu \mathrm{mol} / \mathrm{l}$, which may be one of the probable reasons for choosing this as a target level. Large prospective studies are needed to confirm the antidiabetic effect of urate-lowering drugs.

\section{REFERENCES:}

[1] Chang HW, Lin YW, Lin MH, Lan YC, Wang RY. Associations between urate-lowering therapy and the risk of type 2 diabetes mellitus. PLoS One 2019 Jan 7;14(1):e0210085. doi: 10.1371/journal.pone.0210085.

Disclosure of Interests: Olga Sheliabina: None declared, Maxim Eliseev Speakers bureau: Berlin Chemie Menarini Group, Novartis International AG, EGIS, Aleksandra Novikova: None declared, Maria Chikina: None declared. DOI: 10.1136/annrheumdis-2021-eular 3151 